P-ISSN: 2541-6960; E-ISSN: 2549-8754

Yupa: Historical Studies Journal

Vol. 3 No. 1, 2019 (59-68)

http://jurnal.fkip.unmul.ac.id/index.php/yupa

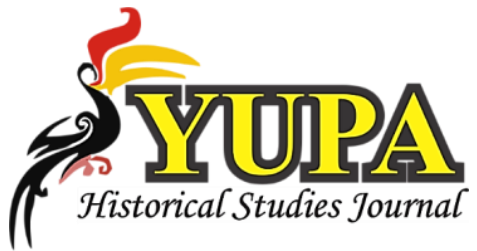

\title{
Dinamika Unit Kegiatan Mahasiswa Pramuka Universitas Negeri Makassar (1978-2013)
}

\author{
Ummi Hafilda Hakim \\ Universitas Muulawarman, Jl. Banggeris No. 89, Samarinda, Indonesia \\ hafildahakimummi@gmail.com
}

\begin{tabular}{ccc}
\hline Received & Accepted & Published \\
$16 / 06 / 2020$ & $04 / 07 / 2020$ & $31 / 07 / 2020$ \\
\hline
\end{tabular}

\begin{abstract}
This historical research aims to find out and describe the Scout Student Activity Unit (UKM) in the IKIP phase until the UNM phase from 1978 to 2012 and its role in shaping the character of students at Makassar State University (UNM). The results showed that scouting UKM of UNM was established in 1978 with the full support of various parties. Institutionally, the scouting UKM in the IKIP and UNM phases did not experience any difference. The pattern of coaching applied refers to the tri bina and tri dharma (rules) of higher education, this is evidenced by the various activities that have been carried out. The existence of Scouting UKM at UNM has a positive contribution or a big role for students with various activities involving students in general to the wider community. Until 2012, this group has shown dynamics that continue to lead to progress even though the dominant obstacle faced is the support of student funds for scouting UKM until 2012 is increasingly minimal.
\end{abstract}

Keywords: Scout, Institution of student, student activity unit

\begin{abstract}
Abstrak Penelitian sejarah ini bertujuan untuk mengetahui dan menggambarkan UKM Pramuka pada fase IKIP hingga fase UNM tahun 1978 sampai tahun 2012 serta perannya dalam pembentukan karakter mahasiswa di UNM. Hasil penelitian menunjukkan, bahwa UKM Pramuka UNM didirikan pada tahun 1978 dengan dukungan penuh dari berbagai pihak. Secara kelembagaan UKM Pramuka pada fase IKIP dan fase UNM tidak mengalami perbedaan. Pola pembinaan yang diterapkan mengacu kepada tri bina dan tri dharma perguruan tinggi, hal ini dibuktikan dengan berbagai kegiatan-kegiatan yang telah dilaksanakan. Keberadaan UKM Pramuka di UNM memberikan kontribusi positif atau peran yang besar terhadap mahasiswa dengan berbagai kegiatan yang melibatkan mahasiswa secara umum hingga masyarakat luas. Hingga sampai tahun 2012, gugusdepan ini telah menunjukkan dinamika yang tetap mengarah kepada kemajuan walaupun kendala dominan yang dihadapi adalah dukungan dana kemahasiswaan untuk UKM Pramuka hingga tahun 2012 semakin minim.
\end{abstract}

Kata kunci: Pramuka, lembaga mahasiswa, unit kegiatan mahasiswa. 


\section{PENDAHULUAN}

Cikal bakal kepanduan pribumi sudah terlihat pada masa Pemerintahan Belanda di Indonesia. Kepanduan lokal pertama lahir di Jakarta pada 1912 dengan nama Nederlance Padvinders Organisatie disingkat NPO (Utomo, 1995). Kemudian, pada 1916, kepanduan pribumi pun terbentuk di Mangkunegaran. Hal ini tidak lepas dari peran Mangkunegoro VII. Kepanduan ini dikenal dengan Javaansche Padvinders Organisatie disingkat JPO (Pujiartati, 2020).

Mengenai pendidikan pada umumnya dan pendidikan kepanduan pada khususnya, maka ditetapkan Gerakan Pramuka sebagai organisasi gerakan pendidikan kepanduan yang tunggal untuk diberi tugas untuk melaksanakan pendidikan tersebut. Gerakan pramuka adalah organisasi pendidikan yang berstatus badan hukum. Gerakan pramuka berkedudukan di ibukota Negara Republik Indonesia untuk Gerakan Pramuka di tingkat nasional, di tingkat daerah berkedudukan di kota Provinsi, di tingkat cabang berkedudukan di kota Kabupaten/Madya, serta di tingkat ranting berkedudukan di kota Kecamatan. Gerakan Pramuka di Indonesia didirikan pada waktu yang tidak ditentukan dan ditetapkan dengan keputusan Presiden Republik Indonesia Nomor 238 Tahun 1961 tanggal 20 Mei 1961, sebagai kelanjutan dan pembaruan Gerakan Pendidikan Kepanduan Nasional Indonesia dan Hari Pramuka diperingati setiap tanggal 1 Agustus. (Kwarnas, 2009) Gerakan Pramuka merupakan wadah yang sifatnya menyeluruh sehingga dapat menyentuh di berbagai kalangan dan aspek kehidupan, salah satu bentuk konkrit adalah terbentuknya Gerakan Pramuka di tingkat perguruan tinggi. Perguruan Tinggi sebagai lembaga pendidikan dapat membentuk gugusdepan yang berbasis satuan pendidikan, sebagaimana ditetapkan dalam pasal 21 Undang-Undang RI Nomor 12 tahun 2010 tentang Gerakan Pramuka, dijelaskan bahwa gugus depan berbasis satuan pendidikan dan gugus depan berbasis komunitas. (Kwarnas, 2009)

Revitalisasi Gerakan Pramuka yang dicanangkan oleh Bapak Presiden RI, selaku Ketua Mabinas Gerakan Pramuka pada hari pramuka ke-45 tanggal 14 Agustus 2006, telah mengalami percepatan sejak Oktober 2009. Revitalisasi Gerakan Pramuka adalah pemberdayaan gerakan pramuka yang sudah ada yang dilakukan secara sistematis, terencana serta berkelanjutan guna memperkokoh eksistensi organisasi organisasi dan lebih meningkatkan peran, fungsi serta pelaksanaan tugas pokok gerakan pramuka. (Kwarnas, 2011) Program Revitalisasi Gerakan Pramuka yang telah direncanakan dan dilaksanakan oleh Kwartir Nasional difokuskan pada pemberdayaan gugusdepan dengan penekanan dan pengembangan pada program-program peserta didik, tenaga pendidik serta prasarana dan sarana pendidikan.

Gerakan pramuka di perguruan tinggi, khususnya di Universitas Negeri Makassar telah memberi kontribusi positif dalam perkembangan dunia kemahasiswaan. Tidak hanya dari segi kuantitatif tetapi juga dari segi kualitatif. Banyaknya kegiatan yang telah dilaksanakan selama ini 
mencerminkan prestasi yang begitu nampak dihati masyarakat sehingga keberadaannya masih diperhitungkan hingga saat ini.

Perkembangan dan peningkatan hasil yang telah dicapai dari awal berdirinya hingga saat ini tidak terlepas dari kendala dan hambatan pada racana Ranggong Dg. Romo dan Opu Dg. Risadju, Gugusdepan Makassar 08-095 - 08-096 Pangkalan Universitas Negeri Makassar yang menggambarkan dinamika UKM Pramuka UNM dari tahun 1978 hingga tahun 2012 seperti kondisi awal UKM Pramuka IKIP hingga perannya dalam dunia kemahasiswaan. Tercatat di tahun 2012, hanya ada tiga lembaga kegiatan mahasiswa tingkat universitas yang baru terbentuk, diantaranya, UKM Profesi yaitu lembaga yang fokus di bidang penelitian dan jurnalis pada tahun 1976 dan UKM Menwa pada tahun 1977.

Pada awal berdirinya UKM Pramuka UNM, tidak banyak mendapat kesulitan, baik dalam hal pendiriannya, koordinasi, konsolidasi dan pendanaannya. Kendala yang dihadapi di awal berdirinya hanya terjadi pada rekrutmen anggota, hal ini disebabkan oleh petunjuk pelaksanaan (Juklak) resmi tentang gerakan pramuka yang berpangkalan di perguruan tinggi belum ada serta kondisi sekretariat yang cukup memprihatinkan karena fasilitas yang minim.

Tulisan ini akan fokus pada uraian dinamika UKM Pramuka UNM dan deskripsi perannya bagi pembentukan karakter mahasiswa di lingkungan kampus khusus pada tahun 1978 hingga tahun 2013.

\section{METODE}

Penelitian ini menggunakan metode sejarah. Metode penulisan sejarah dapat diartikan sebagai cara atau prosedur yang sistematis dalam merekonstruksi masa lampau (M. Saleh Madjid, 2008). Metode juga diartikan sebagai suatu cara atau teknis yang dilakukan dalam proses penulisan pada suatu penelitian (Mardalis, 1999). Tahapan dalam penelitian ini meliputi, heuristik atau pengumpulan sumber, kritik, interpretasi dan historiografi.

Jenis data yang dikumpulkan berupa data primer dan data sekunder. Data primer dapat diperoleh dengan melalui penelitian langsung ke lokasi penelitian untuk mengadakan wawancara (interview) dan observasi dengan pelaku atau orang-orang yang mengetahui tentang topik penulisan tersebut serta pengelolaan dokumen atau arsip kegiatan yang berkaitan dengan objek yang dikaji. Teknik wawancara yang digunakan berupa interview guide atau dengan menggunakan pedoman wawancara, namun tidak terikat dengan pedoman yang ada mengingat dalam situasi yang sebenarnya akan sulit untuk selalu berpedoman pada panduan yang ada. (Idrus, 2009). Selain itu penulis juga menggunakan arsip lembaga berupa laporan-laporan kegiatan sebagai data primer mengingat belum ada penelitian yang dilakukan sebelumnya.

Sedangkan data sekunder diperoleh melalui pengkajian sumber-sumber baik berupa dokumen ataupun buku-buku yang ada hubungannya dengan objek yang di teliti. Adapun sumber 
yang sifatnya sekunder berupa artikel sebagai bahan pembanding diperoleh di Makassar dengan mendatangi sejumlah perpustakaan, yakni perpustakaan dalam lingkup Universitas Negeri Makassar dan perpustakaan milik UKM Pramuka.

Tahapan kritik dan interpretasi, penulisa melakukan pemilahan data yang sesuai dengan kebutuhan dan diurutkan secara kronologis sesuai dengan kajian serta melakukan penafsiran secara objektif sehingga memudahkan penulis dalam melakukan historigrafi pada tahap akhir. Sedangkan pada tahap akhir yaitu penulisan hasil penelitian secara kronologi dengan menggunakan ilmu-ilmu bantu sejarah lainnya

\section{HASIL DAN PEMBAHASAN}

\section{Kondisi Awal UKM Pramuka IKIP Ujungpandang}

Direktorat Jenderal Pendidikan Perguruan Tinggi Departemen Pendidikan dan Kebudayaan Republik Indonesia sebagai pengambil kebijakan tentang pengembangan sumber daya perguruan tinggi, telah memikirkan untuk menciptakan wadah pengembangan bakat dan minat mahasiswa di bidang kepanduan.

Untuk mengembangkan pendidikan kepanduan di lingkungan perguruan tinggi, maka diadakanlah kerja sama oleh pihak Kwartir Nasional Gerakan Pramuka yang menyelenggarakan pertemuan utusan seluruh perguruan tinggi Se-Indonesia pada bulan April 1978 yang bertempat di Universitas Padjajaran Bandung. Pertemuan ini membahas mengenai pembentukan organisasi kepramukaan yang berpangkalan di perguruan tinggi.

Pertemuan tersebut diikuti oleh delegasi IKIP Ujungpandang yang diwakili Jamal dan Erma (Tim Penyusun, 2003). Setelah kegiatan tersebut, delegasi IKIP Ujungpandang langsung mengadakan pertemuan dengan pimpinan IKIP UP. Hasil pertemuan itu ditindaklanjuti dengan pertemuan unsur fakultas melalui dewan mahasiswa, kemudian diputuskan untuk membentuk Gugusdepan yang berpangkalan di IKIP Ujungpandang.

UKM Pramuka IKIP pada awalnya tidak banyak menemui hambatan dari segi koordinasi, konsolidasi, dan pendanaan hanya saja, pada saat itu Pramuka masih terkendala pada jumlah anggota yang minim sehingga pengurus pramuka pada saat itu diberikan uang operasional sebagai langkah meningkatkan sumber daya anggota. Fasilitas pada UKM Pramuka pada saat itu juga masih minim atau masih perlu diperbaharui. Menurut Andi Bakri Mangkau selaku Ketua Gugusdepan 08.095 pangkalan Universitas Negeri Makassar.

Tepat pada tanggal 1 Mei 1978 bertempat di Kampus IKIP Gunungsari Baru saat itu, Gugusdepan yang berpangkalan di IKIP Ujung Pandang resmi berdiri dengan nomor 355 - 356 (Tim Penyusun, 2003).

Beberpa orang yang dianggap sebagai peletak sekaligus sebagai penanda kehadiran gugusdepan, seperti Jamal Abdul Nasser, Djuhapong, Nur Habiba Lubis, Erma Rahman, Yusuf A. 
Ngampo, Sitti Nurbaya, Nuhung Rais, Jamila, Mustaming, Kartini, Arif Piana dari pihak mahasiswa. Sementara dari pihak dosen yang turut berpartisipasi adalah Abd Karim (Rektor IKIP), Said Muchtar, Soetinah Soewondo, Saenong P., Wahid, Anas Ponreng, Teho, Jaelani, Hj. Andi Supiah Anas, Suleha, Hj. Pahisa (Tim Penyusun, 2003).

Program kerja pada awal berdirinya UKM Pramuka IKIP diwujudkan dalam bentuk pembentukan Desa Binaan di Cadika Limbung dan atas rekomendasi dan bantuan H. Yasin Limpo Ketua Kwartir Daerah pada saat itu. Selain itu kegiatan-kegiatan pada awal berdirinya berjalan dengan baik seperti pencapaian SKU, latihan rutin serta kegiatan teknik kepramukaan lainnya tanpa melupakan bina masyarakat dan bina satuan. Seperti yang diungkapkan oleh Hj. Andi Supiah Anas Selaku pembina Racana Opu Dg. Risadju pada tahun 1978,

Hubungan intern yang baik dari awal antara jajaran pejabat kampus, Pembina, pengurus dan anggota hingga saat ini tetap terjalin. Hubungan kekeluargaan berusaha diciptakan dengan memperbanyak kegiatan di lapangan.

\section{Sistem Keanggotaan UKM Pramuka UNM}

Mengetahui keadaan Proses pembinaan pada UKM Pramuka, ada beberapa tahap yang dilalui oleh anggota yaitu orientasi dan perkemahan pengenalan medan. Dalam orientasi yang dilaksanakan selama 1 (satu) bulan tersebut anggota diberikan materi-materi tentang Gerakan Pramuka di dunia maupun di Indonesia. Setelah pemberian materi, tahap selanjutnya adalah perkemahan pengenalan medan. Tujuan dari pengenalan medan ini adalah unutk mengaplikasikan mater-materi selama orientasi dan penerapannya di dalam masyarakat. Proses pembinaan dari tahun 1978 - 2012 pada dasarnya sama, hanya saja teknis pada kegiatannya yang berbeda karena kegiatan penerimaan anggota baru diberikan tanggung jawab penuh kepada sangga kerja atau panitia yang telah ditunjuk oleh pengurus dan disetujui Pembina.

Selanjutnya, mengenai struktur organisasi dewan racana (pengurus UKM Pramuka). Racana UKM Pramuka UNM diberi nama Racana Ranggong Dg. Romo untuk pramuka putra dan Opu Dg. Risadju untuk pramuka putri, Racana UKM Pramuka dipimpin oleh seorang putra dan seorang putri yang disebut Ketua Dewan Racana Putra dan Putri. Dalam kepengurusan, ketua Dewan Racana dibantu oleh sekretaris, Bendahara, Pemangku Adat, dan Ketua Bidang yang masing-masing dibantu oleh anggota Divisi. Adapun bidang-bidang yang dimaksud, yatu:

1. Bidang Keilmuan dan Kerohanian

2. Giat dan Teknik Kepramukaan

3. Penelitian dan Pengembangan

4. Sarana dan Prasarana.

5. Informasi dan Komunikasi

Pengurus UKM Pramuka diberikan kesempatan selama satu tahun dalam melaksanakan dan merealisasikan program kerja yang telah dirumuskan di musyawarah. Masa bakti pengurus 
UKM Pramuka yaitu satu tahun, sesuai dengan aturan Gerakan Pramuka di perguruan tinggi tahun 2011 (Kwarnas, 2009).

\section{Quo Vadis UKM Pramuka}

Pada awal periode yaitu tahun 1987, tidak terlalu banyak program kerja yang dilaksanakan seperti organisasi kampus pada umumnya karena pada masa ini, UKM Pramuka masih fokus pada perkembangan sumber daya anggota dimana pola pembinaan bagi anggota yang meliputi kepercayaan diri, pemberian bekal dan kemampuan dan keterampilan, membentuk anggota yang siap mendorong dan melibatkan diri dalam pengabdian masyarakat.

Bentuk kegiatan awal periode itu berupa kerjasama dengan pihak lembaga pramuka di tingkat provinsi yang diwujudkan dengan membentuk desa binaan yang berlokasi di Cadika Limbung (Desa Pa'bentengan). Selain desa binaan, kegiatan lainnya lebih bersifat partisipatif dan pembinaan anggota serta kerja sama dengan lembaga pramuka dari universitas lain seperti UNHAS dan IAIN yang sama-sama baru terbentuk.

Pada awal pembentukan gugusdepan ini (1978) hanya tercatat 64 anggota (putra : 28, putri : 36). Perkembangan jumlah anggota mengalami peningkatan dari tahun ke tahun. Hingga tahun 1984 tercatat

Pada periode tahun 1991 - 1995, aktivitas UKM Pramuka semakin mantap menggunakan pola pembinaan dan perkembangan anggota. Pada tahun yang sama, UKM kemudian membentuk lembaga khusus untuk anak usia sekolah. Pembentukan lembag ini didasari atas kondisi objektif, bahwa dalam lingkungan IKIP Ujung Pandang terdapat beberapa potensi lembaga pendidikan, seperti SD, SLTP, dan SMU yang telah bekerjasama dengan IKIP UP sebelumnya.

Anggota UKM Pramuka banyak berperan terhadap proses pembinaan di berbagai sekolah-sekolah yang ada di Makassar dan Gowa. Periode ini merupakan masa terbanyak keanggotaannya yaitu 242 putra dan 471 putri. Dari tahun 1990 hingga tahun 1995 jumlah anggotanya sekitar 713 orang. Jumlah ini adalah jumalh tertinggi selama penerimaan anggota.

Pada usia 25 tahun UKM Pramuka, keberadaan lembaga pramuka di perguruan tinggi semakin diperhitugkan, namun ternyata hal tersebut memberikan peluang kepada salah satu fakultas di UNM membentuk lembaga pramuka yang baru. Secara aturan, tidak diperkenankan membentuk lebih dari satu lembaga pramuka dalam satu institusi sehingga hal ini yang kemudian menciptakan polemik. Sehingga hingga saat ini, terdapat dua lembaga pramuka di UNM, dimana UKM Pramuka di bawah naungan Universitas, sedangkan lembaga pramuka yang baru terbentuk di bawah naungan Fakultas Ilmu Pendidikan UNM. Terbentuknya lembaga tersebut adalah salah satu dampak dari komunikasi yang kurang maksimal dan sosialisai tentang aturan pramuka di lembaga perguruan tinggi.

Masa IKIP Ujung Pandang para anggota berasal dari jurusan keguruan atau yang berlatar pendidikan guru sehingga UKM Pramuka tidak menemui hambatan yang berat dalam proses 
pembinaan sedangkan pada masa UNM, UKM Pramuka memberikan peluang kepada seluruh mahasiswa UNM sehingga yang tidak memiliki latar belakang calon pengajar juga harus mampu melakukan proses pembinaan sehingga hal ini menjadi tantangan yang besar untuk melahirkan calon Pembina pramuka yang siap mengabdi di tengah masyarakat.

Pada tahun 2006, jumlah mahasiswa yang bergabung pada UKM semakin menurun, hal ini adlah salah satu dampak dari aturan akademik yang diberlakukan oleh universitas pada saat itu, sehingga aktifitas kelembagaan seakan terabaikan dan seolah menjadi hal yang menakutkan dan berpotensi menghambat prestasi akademik. Hal ini memaksa para pengurus lembaga untuk menentukan strategi dalam mempertahankan eksistensi lembaga. Khusus UKM Pramuka, para anggota aktif melakukan sosialisi pentingnya berorganisasi baik itu berupa sosialisasi langsung maupun tidak langsung (brosur)

Pemberlakuan Undang-Undang Republik Indonesia Nomor 12 Tahun 2010 tentang Gerakan Pramuka dan pramuka sebagai eskul wajib di sekolah pada tahun 2011 memberikan dampak yang siginifikan bagi UKM Pramuka. Jumlah anggota semakin hari semakin meningkat.

\section{Peranan UKM Pramuka UNM dalam Pembentukan Karakter Mahasiswa UNM}

Keberadaan UKM Pramuka seperti sekarang ini adalah manifestasi perjalanan sejarah pada masa lalu karena bagaimanapun dimensi historis tidak bisa dipisahkan dari semua dimensi kehidupan generasi muda masa kini. UKM Pramuka merupakan perwujudan partisipasi langsung dari keinginan masyarakat IKIP - UNM untuk meraih komponen masa depan yang lebih baik, karena dengan keberadaan UKM ini diharapkan dapat memacu prestasi anak didik.

Wujud lain yang merupakan manifestasi dari upaya pembaharuan dalam bidang pendidikan di UKM adalah pergeseran peran guru dan siswa. Pada awalnya guru biasa disebut "Mr Of Know" atau guru yang serba tahu, nampaknya untuk kondisi sekarang anggapan tersebut telah berubah. Guru tidak lagi dianggap orang serba tahu yang merupakan pusat sumber belajar, akan tetapi ia lebih tepat dikatakan sebagai orang yang bertugas mengelola kegiatan belajar.

Kesepakatan organisasi merupakan pengejawantahan dari kedaulatan mahasiswa yang sadar akan pentingnya kebebasan berfikir dan keadilan yang kemudian mampu untuk menentukan hal yang baik dan yang buruk. Mahasiswa telah membuktikan peranannya sebagai insane intelektual dan bermoral yang diselimuti oleh khasanah religious dan ilmiah, sehingga kesadaran akan suatu kebenaran itu memiliki peranan guna menunjang fungsi kontrolnya.

UKM Pramuka UNM merupakan lembaga pengkaderan sesuai dengan bakat dan minat mahasiswa. UKM Pramuka adalah salah satu lembaga ekstrakurikuler yang banyak berperan dalam pengembangan dan pembentukan keterampilan mahasiswa terutama dalam bidang kepramukaan.

Adanya berbagai perilaku menyimpang dari generasi muda khususnya dikalangan mahasiswa mengindikasikan ada hal-hal yang perlu dibenahi dalam proses pendidikan kita 
sehingga menjadi manusia seutuhnya yang ditandai dengan munculnya kesadaran untuk bertanggungjawab terhadap dirinya sendiri, masyarakat, bangsa dan Negara, serta lingkungan. Pendidikan yang dilakukan selama ini, termasuk pendidikan kewarganegaraan dan agama yang diharapkan menjadi instrument pendidikan moral dan karakter bangsa belum mencapai hasil yang maksimal walaupun pendidikan serupa diperoleh mulai dari pendidikan dasar hingga perguruan tinggi.

UKM Pramuka dianggap bisa meminimalkan sikap-sikap menyimpang di kalangan mahasiswa yang terjadi belakangan ini. Gerakan Pramuka bukan hanya mendidik anak agar terbiasa untuk hidup berdisiplin, tetapi juga jujur, bekerja keras, suka menolong sesama, dan mempunyai sikap toleran terhadap perbedaan. Mereka juga bukan hanya diberi pengetahuan, tetapi juga langsung mempraktekkan pengetahuan tersebut dalam realitas yang sesungguhnya, serta diajari belajar dari realitas tersebut.

Memang harus diakui bahwa kedudukan UKM Pramuka UNM sebagai salah satu unit kegiatan mahasiswa masih memiliki daya tarik yang rendah. Padahal pendidikan kepramukaan memiliki peran yang besar terhadap mahasiswa khususnya mahasiswa UNM yang berlatarbelakang seorang calon tenaga pengajar.

UKM Pramuka UNM hingga saat ini telah membuktikan bahwa lembaga tersebut memiliki peran dan fungsi bagi mahasiswa dan kampus baik dalam segi pembentukan karakter hingga dari segi realisasi kegiatan-kegiatan yang positif.

Berdasarkan uraian diatas maka dapat digambarkan bahwa UKM Pramuka bisa dijadikan sebagai alat dan alternatif dalam pembentukan karakter mahasiswa melalui kegiatan-kegiatan yang dilaksanakan dan prestasi yang telah diraih sehingga mempertegas kedudukan peran dan fungsi UKM Pramuka yang selalu berorientasi pada pembentukan karakter yang dituangkan dalam setiap kegiatan yang bernilai edukasi. Padatnya jadwal kegiatan yaitu program kerja yang direncanakan maupun bersifat partisipan dianggap bisa menyita waktu para anggota sehingga meminimalkan munculnya kegiatan yang bersifat negatif atau menyimpang dikalangan mahasiswa.

Prestasi UKM Pramuka sejak tahun 1987 hingga 2013 terlihat dari angka partisipasi yang tinggi dalam berbagai kegiatan, baik itu kegiatan akademik maupun kegiatan pramuka, serta kegiatan skala daerah maupun skala nasional.

Faktor pendukung dalam setiap kegiatan usaha merupakan hal yang dapat menunjang kegiatan usaha tersebut dalam proses pertumbuhan dan perkembangannya. Untuk itu dapat dikemukakan beberapa faktor pendukung sebagai berikut :

Adanya kemauan yang kuat dari seluruh anggota dalam proses pembinaan dan pengembangan UKM Pramuka UNM

1. Adanya dukungan dari unsur mabigus dalam setiap kegiatan 
2. Adanya dukungan dari para purna dan unsur mabigus

3. Adanya dukungan moril, materil, dan pemikiran dari Pembina dan purna UKM Pramuka

4. Adanya bantuan dan dukungan dari beberapa instansi terkait

5. Adanya dukungan dari pihak Kwartir Daerah Sulawesi Selatan dan Kwartir Cabang Makassar.

Adapun faktor yang menjadi penghambat pada UKM Pramuka UNM dalam upaya melaksanakan proses pembinaan dan merealisasikan program-program kerjanya yaitu:

1. Semakin minimnya Dana Kemahasiswaan yang dialokasikan untuk UKM di Universitas Negeri Makassar.

2. Rendahnya minat mahasiswa yang menjadikan UKM Pramuka sebagai pilihan dalam proses belajar organisasi.

3. Penggolongan usia untuk golongan penegak dan pandega dalam pencapaian Syarat Kecakapan Umum (SKU) belum maksimal.

\section{KESIMPULAN}

Pembentukan Gugusdepan IKIP Ujungpandang diawali dengan adanya edaran surat dari Direktorat Jenderal Pendidikan Tinggi bekerja sama dengan Kwartir Nasional Gerakan Pramuka untuk pembentukan wadah pengembangan bakat dan minat mahasiswa di bidang kepanduan. Melalui delegasi IKIP Ujungpandang dalam pertemuan perguruan tinggi Se-Indonesia kemudian dibentuklah Gugusdepan IKIP Ujungpandang tepat pada tepat pada 1 Mei 1978.

Kondisi awal UKM Pramuka IKIP tidak banyak menemui hambatan dari segi koordinasi, konsolidasi, dan pendanaan hanya saja pramuka pada saat itu masih terkendala pada jumlah aggota dan fasilitas sekretariat yang masih minim.

UKM Pramuka pada fase IKIP dan UKM Pramuka pada fase UNM secara organisasi tidak memiliki perbedaaan karena program kerja dan kegiatan-kegiatan tetap berjalan normal, tapi dari segi sumber daya anggota fase UNM lebih berat tantangannya karena UKM Pramuka telah menerima anggota yang tidak memiliki latar belakang guru yang salah satu program utama UKM adalah menyiapkan calon pembina di sekolah.

UKM Pramuka juga merupakan wadah pengembagan dan pembetukan karakter mahasiswa melalui pemberian peluang kepada seluruh mahasiswa untuk terlibat dalam proses pembinaan generasi muda dan melakukan kegiatan-kegiatan positif sehingga meminimalkan mahasiswa melakukan tindakan-tindakan negatif yang akan merugikan dirinya sendiri secara khusus dan universitas secara umum.

Semakin minimnya alokasi dana kemahasiswaan bagi UKM Pramuka sehingga program kerja belum berjalan maksimal serta rendahnya minat mahasiswa untuk bergabung dalam UKM 
Pramuka. Namun, kemauan keras dari para anggota, pengurus dan pembina dalam merealisasikan program kerja dan melakukan proses pembinaan serta dukungan dari berbagai pihak dalam setiap pelaksanaan kegiatan adalah hal yang patut diapresiasi.

\section{REFERENSI}

Abdullah, Taufik dan Abdurracman Surjamiharjo, 1985.Historiografi Sejarah. Jakarta: Gramedia.

Helius Sjamsuddin. 2007. Metodologi Sejarah. Yogyakarta: Ombak.

Kementerian Pemuda dan Olahraga, 2011. Undang-undang Republik Indonesia Nomor 12 Tahun 2010 tentang Gerakan Pramuka, Kementerian Pemuda dan Olahraga Republik Indonesia, Jakarta.

Kwartir Nasional Gerakan Pramuka, 2010. Gerakan Pramuka Anggaran Dasar Keppres No:24 Tahun 2009 tentang Pengesahan Anggaran Dasar Gerakan Pramuka dan Anggaran Rumah Tangga SK Kwarnas No: 203 Tahun 2009 Tentang Anggaran Rumah Tangga Gerakan Pramuka. Pustaka Tunasmedia, Jakarta.

Kwartir Nasional Gerakan Pramuka, 2011. Petunjuk Pelaksanaan Gugus Depan Gerakan Pramuka yang Berpangkalan di Kampus Perguruan Tinggi SK Kwarnas No.180 A Tahun 2011. Kwartir Nasional Gerakan Pramuka, Jakarta.

Idrus Muhammad, 2009. Metode Penelitian Sosial. Erlangga, Jakarta.

Madjid, Muh. Saleh, Hamid, Abd. Rahman. 2008. Pengantar Ilmu Sejarah. Makassar: Rayhan Intermedia

Mardalis, Drs, 1999. Metode Penelitian suatu Pendekatan Proposal. PT. Bumi Aksara, Jakarta.

Sugiyono, 2010. Metode Penelitian Pendidikan Pendekatan Kuantitatif, Kualitatif, dan R\&D. Alfabeta, Bandung.

Sunardi BOB Andri, 2006. Boyman Ragam Latih Pramuka, Penerbit Nuansa Muda, Bandung.

Tim Penyusun, 2003. 25 Tahun Gugusdepan 355-356 Universitas Negeri Makassar. Hamrin Production, Makassar.

Adat Racana Ranggong Dg.Romo dan Opu Dg.Risadju Tahun 2012 - 2013

Laporan Hasil Kegiatan UKM Pramuka dari masa ke masa

Prestasi-prestasi UKM Pramuka Universitas Negeri Makassar

Pujiartati, R. (2020). The Existence of First Indigenous Scouting Javaansche Padvinders Organisatie in Mangkunegaran. Yupa: Historical Studies Journal, 3(1), 38-48. https://doi.org/10.30872/yupa.v3i1.168

Utomo, C. B. 1995. Dinamika Pergerakan Kebangsaan Indonesia: dari Kebangkitan hingga Kemerdekaan. Semarang: IKIP Semarang Press. 